\title{
Pengaruh Sosialisasi Layanan Mobile Banking dan Persepsi Nasabah Terhadap Kepercayaan Nasabah Bank NTT Cabang Ende
}

\author{
Fransiskus Korosando ${ }^{1 *}$, Ludvina Fince ${ }^{2}$ \\ ${ }^{1,2}$ Program Studi Pendidikan Ekonomi Universitas Flores Ende \\ Jln. Samratulangi, Kelurahan Paupire, Ende \\ ${ }^{*}$ Corresponding Author: atatomberabu@gmail.com
}

\begin{tabular}{l}
\hline Info Artikel \\
\hline Sejarah Artikel: \\
Diterima: $28 / 02 / 2020$ \\
Direvisi: 05/03/2020 \\
Disetujui: 18/03/2020 \\
\hline Keywords: \\
socialization of $m$ - \\
banking services, \\
perception \\
\hline
\end{tabular}

\section{Abstract}

The purpose of this study is to describe (1) the effect of the socialization of the Mobile banking service (m-banking) on the trust of Bank NTT Customers in the Ende Branch; (2) the effect of customer perceptions on the trust of NTT Bank Ende Branch Customers; (3) the effect of the socialization of the Mobile banking service (m-banking) and the customer's perception of the trust of the Customers of the NTT Bank Ende Branch. This research is a quantitative study with primary data obtained using a questionnaire technique. Bank NTT Ende Branch customers of the Ende Regency Government ASN profession category as the study population. The research sample uses a simple random sampling technique with accidental sampling approach. The results of the partial test analysis ( $t$ test) the effect of sosilaisasi m-banking services on trust shows sig. > 0.05. Partial test ( $t$ test) the effect of customer perception on the trust of customers of the Ende Bank NTT branch shows sig. > 0.05. Simultaneous test ( $f$ test) of M-banking service socialization, customers' perceptions of the trust of Bank NTT customers in the Ende Branch showed sig > 0.05. The results of the analysis concluded the service socialization variable, and customer perceptions did not significantly influence trust. Thus the hypothesis proposed "not accepted".

\begin{abstract}
Abstrak
Tujuan penelitian ini untuk mendeskripsikan (1) pengaruh sosialisasi layanan Mobile banking (m-banking) terhadap kepercayaan Nasabah Bank NTT Cabang Ende; (2) pengaruh persepsi nasabah terhadap kepercayaan Nasabah Bank NTT Cabang Ende; (3)pengaruh sosialisasi layanan Mobile banking (m-banking) dan persepsi nasabah terhadap kepercayaan Nasabah Bank NTT Cabang Ende. Penelitian ini merupakan penelitian kuantitatif dengan dataprimer diperoleh menggunakan teknik angket.Nasabah Bank NTT Cabang Ende kategori profesi ASN Pemerintahan Kabupaten Ende sebagai populasi penelitian.Sampel penelitian menggunakan teknik porposive simple random sampling dengan pendekatan accidental sampling. Hasilanalisis uji parsial (uji t) pengaruh sosilaisasi layanan $m$-banking terhadap kepercayaan menunjukkan sig. > 0,05. Uji parsial (uji t) pengaruh persepsi nasabah terhadap kepercayaan nasabah Bank NTT cabang Ende menunjukkan sig. > 0,05. Uji simultan (uji f ) sosialisasi layanan $m$-banking, persepsi nasabah terhadap kepercayaan nasabah Bank NTT Cabang Ende menunjukkan sig > 0,05. Hasil analisis tersebut disimpulkan variabel sosialisasi layanan, dan persepsi nasabah tidak berpengaruh signifikan terhadap kepercayaan. Dengan demikian hipotesis yang diajukandianyatakan "ditolak".
\end{abstract}

\footnotetext{
*Alamat korespondensi:

Program Studi Pendidikan Ekonomi

Jln. Samratulangi, Kelurahan Paupire, Ende, NTT

E-mail: atatomberabu@gmail.com

(C) 2020 Program Studi PGSD Universitas Flores

Email: primagistrauniflor@gmail.com
} 


\section{PENDAHULUAN}

\section{A. Latar Belakang}

Kemajuan teknologi digitalisasi memudahkan manusia untuk mengakses informasi layanan jasa perbankan, cukup dengan menggunakanhandphone atau android yang terkoneksi dengan jaringan internet maka seseorang dapat melakukan transaksi secara online,yang juga disebut sebagai layanan mobile banking atau m-banking. Pada dunia perbankan pada umumnya mengadaptasikan layanan ini untuk memudahkan para nasabahnya dalam bertransaksi tanpa harus pergi ke kantor pelayanan bank, tetapi cukup di rumah atau dimana saja berada dapat melakukan transaksi. Secara khusus, layanan ini juga menjadi salah satu bentuk pelayanan yang digunakan oleh Bank NTT dalam rangka mewujudkan visi "menjadi bank yang sehat, kuat, dan terpercaya", dalam semboyan "melayani lebih sungguh".

Terdapat kegunaan yang diperoleh para nasabah dalam bertransaksi dengan menggunakan layananm-banking seperti yang dikemukakan Harish (2017:14) yaitu: (1) Mudah: Untuk melakukan transaksi perbankan kita tidak perlu datang langsung kebank, kecuali pada saat kita mendaftarkan nomor ponsel; (2) Praktis: Setiap nasabah dapat langsung bertransaksi perbankan melaui ponsel setiap saat kapan saja dan dimana saja; (3) Aman: m-banking dapat dilengkapi dengan sistem proteksi yang maksimal secara otomatis sudah terprogram sejak pendaftaran. Selain menggunakan pin yang dapat dipilih sendiri dengan nomor ponsel yang didaftarkan, setiap transaksi yang dilakukan juga akan diacak untuk menjamin keamanan para nasabah.

Secara emprik kelompok nasabah Aparatus Sipil Negara Kabupaten Ende (ASN Kab.Ende) sebagai salah satu kelompok yang mendapat sosialisasi layanan m-banking dengan maksud layanan ini dapat dimanfaatkan karena memberikan kemudahan kepada nasabah ASN Kab.Ende bertransaksi. Sosialisasi pada kategori ini dilakukan dengan cara tatap muka dan mendemonstrasikan penggunaakan aplikasi m-banking yang terinstal dalam perangkat handphone/android.

Harapan yang tersirat dalam sosialisasi di atas dalam realitasnya belum mencapai hasil yang maksimal. Artinya ASN Kab. Ende cenderung memanfaatkan layanan yang lain seperti transaksi secara langsung di Kantor Bank NTT yang ada di Kabupaten Ende dan anjungan tunai mandiri yang disiapkan dibeberapa titik di Kota Ende dan sekitarnya. Hal ini diduga karena para nasabah memiliki referensi dan informasi yang dipublikasikan media terkait pembobolan uang oleh oknum yang tidak bertanggungjawab sehingga menimbulkan kerugian bagi para nasabah bahkan reputasi dari bank itu sendiri. Selain itu penggunaan m-banking juga memiliki ketergantungan dengan provider yang menyediakan jaringan internet, ketika terjadi gangguan jaringan maka akses melalui $m$-banking akan terhambat. Banyak kasus yang terjadi sehari-hari seperti pembobolan tabungan nasabah melalui ATM yang dilakukan oleh pihak-pihak tertentu yang merugikan nasabah/pelanggan. Tentu hal ini akan berdampak terhadap tingkat kepuasan nasabah/pelanggan (Syamsul Rizal, dan Munawir,2017).

Berlandaskan pada paparan diatas, peneliti tertarik untuk mengkaji pengaruh sosialisasi layanan m-banking dan persepsi terhadap kepercayaan nasabah bank NTT Cabang Ende.

\section{B. Kajian Pustaka}

\section{Sosilaisasi}

Sosialisasi dapat dikatakan sebagai bentuk tindakan untuk menyampaikan informasi tertentu dalam bentuk penyampaian verbal, simulasi/tutorial, demonstrasi, dengan maksud dan tujuan tertentu. sosialisasi mengandung maksud keinginan untuk mengkomunikasikan dan menanamkan nilai-nilai tertentu yang sesuai dengan keinginan pemberi informasi/lembaga tertentu dengan harapan penerima informasi dapat mengaktualisasikannya.

$$
\text { Yuwono (2015:6) "Sosialisasi }
$$
merupakan suatu proses dimana orang-orang 
mempelajari sistem nilai, norma dan pola perilaku yang diharapkan oleh kelompok dalam bentuk trasformasi dari orang tersebut sebagai orang luar menjadi organisasi yang efektif".

Dominick dalam Effendy (2003:31), sosialisasi merupakan transmisi nilai-nilai (transmission of values) yang mengacu kepada cara-cara dimana seseorang mengadopsi perilaku dan nilai-nilai dari suatu kelompok. Asmara \& Aryateja (2006: 58) menjelaskan bahwa sosialisasi dapat berwujud penyebaran informasi melalui media massa dan penyuluhan.

\section{Layanan}

Pelayanan merupakan bentuk dari perhatian yang diberikan oleh satu pihak kepada pihak yang lain. Pelayanan dapat diberikan kepada individu maupun kepada kelompok tertentu dengan tujuan memberikan kepuasan. Kotller (2003:464) mengemukakan pelayanan (service) adalah suatu tindakan ataupun kinerja yang biasa diberikan kepada orang lain. Moenir (2010:26) "pelayanan adalah kegiatan yang dilakukan seseorang atau sekelompok orang dengan landasan faktor materi melalui sistem, prosedur dan metode tertentu dalam rangka usaha memenuhi kepentingan orang lain sesuai dengan haknya". Kepuasan pelanggan karena kebutuhannya terpenuhi mencitrakan kualitas pelayanan, sehingga reputasi perusahaan akan semakin dipercayai.

Zeithaml et-al (1996) mengemukakan kualitas layanan (service quality) mempengaruhi kepuasan pelanggan serta nilai-nilai pelanggan dan dengan demikian mempengaruhi loyalitas pelanggan. Cronin dan Taylor (1992) mengidentifikasi kualitas pelayanan sebagai anteseden kepuasan dan berpendapat bahwa kualitas layanan (service quality) memiliki dampak yang lebih rendah pada niat dibandingkan dengan kepuasan konsumen. Kepuasan pelanggan yang menerima layanan juga melibatkan jalinan hubungan, dan semua jenis hubungan membutuhkan kepercayaan. Selain itu, penelitian sebelumnya telah mengidentifikasi bahwa kepercayaan merupakan salah satu faktor penentu dari loyalitas pelanggan (Aydin dan Ozer,2005).

\section{Mobile m-banking}

M-banking memberikan kemudahan bagi nasabah untuk melakukan transaksi perbankan seperti pengecekan saldo, transfer dana antar rekening, dan pembayaran tagihan. Hal ini dapat dilakukan oleh nasabah kapan dan dimana saja selama 24 jam dalam 7 hari. Dengan m-banking nasabah dapat melakukannya dengan sangat mudah tanpa harus datang dan antre ke kantor perbankan atau ke mesin ATM untuk melakukan transaksi perbankan.

M-banking merupakan suatu produk layanan perbankan berbasis handphone yang ditawarkan kepada nasabah untuk melakukan transaksi perbankan secara mudah. Harish, (2017:14), kegunaan yang dapat diperoleh dari penggunaan m-banking yaitu: (1) Mudah: Untuk melakukan transaksi perbankan kita tidak perlu datang langsung ke bank, kecuali pada saat kita mendaftarkan nomor ponsel; (2) Praktis: Setiap nasabah dapat langsung bertransaksi perbankan melalui ponsel setiap saat kapan saja dan dimana saja; (3) Aman: m-banking dapat dilengkapi dengan sistem proteksi yang maksimal secara otomatis sudah terprogram sejak pendaftaran. Selain menggunakan pin yang dapat dipilih sendiri dengan nomor ponsel yang didaftarkan, setiap transaksi yang dilakukan juga akan diacak untuk menjamin keamanan para nasabah.

Kehadiran handphone dan layanan mobile banking dalam transaksi perbankan yang biasanya dilakukan secara manual atau kegiatan yang sebelumnya dilakukan nasabah dengan mendatangi bank, kini dapat dilakukan tanpa harus mengunjungi gerai bank, hanya dengan menggunakan handphone nasabah dapat menghemat waktu dan biaya. Layanan mobile banking memberikan kemudahan kepada para nasabah untuk melakukan transaksi perbankan seperti cek saldo, transfer antar rekening, pembayaran tagihan dan isi pulsa (Novitasari Putri Wulandari, dkk, 2017). Dalam pelayanan jasa m-banking selain memiliki kelebihan, juga memiliki resiko, seperti yang ditemukan oleh Selly Maulina, Dahlan, Mujibussalim, (2016) diantaranya, pembayaran mobile banking secara otomatis 
ter-log out, sehingga nasabah melakukan pembayaran yang kedua kalinya karena pembayaran yang pertama dinyatakan gagal terkirim. Setelah dilakukan pengecekan ternyata rekening nasabah telah terdebet dua kali. Hal lainnya adalah nasabah merasa kurangnya keamanan password yang mengakibatkan nasabah merasa dirugikan terhadap aplikasi online yang secara otomatis mendebet dari rekening nasabah.

\section{Persepsi}

Persepsi adalah tanggapan langsung dari individu akan sesuatu produk yang disediakan untuk suatu kepentingan. Menurut Rakhmat (2012:50) mendefinisikan "persepsi sebagai pengalaman tentang objek peristiwa atau hubungan-hubungan yang diperoleh dengan mengumpulkan informasi dan menafsirkan pesan".

Proses persepsi seseorang individu dipengaruhi oleh lingkungan dan juga informasi yang diperolehnya. Robbins, (2003: 160-161) mengemukakan pembentukan persepsi dipengaruhi oleh (1) Pelaku persepsi; (2) target atau objek.

\section{Kepercayaan}

Kepercayaan dapat dikatakan sebagai bentuk kesediaan dari seseorang untuk melaksanakan kegiatan tertentu yang berkaitan dengan pengelolaan keuangan seseorang oleh lembaga keuangan yang dihasilkan oleh proses interaksi sebelumnya. Kepercayaan juga disebut sebagai keyakinan bahwa uang seseorang akan aman, terlindungi dan memudahkan pemiliknya ketika sesewaktu membutuhkan uangnya untuk digunakan dalam rangka memenuhi kebutuhannya.

Hubungan interaksi dan transaksi yang terjaga dengan baik akan meningkatkan kepercayaan pada lembaga keuangan yang memberikan pelayanan berkualitas, dan terjamin keamanan finansial. Charles Handy dalam Oetomo (2006) menyebutkan dengan istilah Trust the virtual organization, yang dapat dibangun melalui seven riles of trust, yaitu:

1. Trust is not blind. Kepercayaan bukan suatu yang buta. Dalam pengertian ini sebuah loyalitas yang muncul atas dasar kepercayaan selalu membutuhkan proses serta bukti bahwa produk yang dipercayai konsumen kepercayaannya benar-benar berkualitas.

2. Trust need boundaries. Kepercayaan tanpa batas adalah tidak realistis. Kepercayaan dibangun atas dasar tertentu. Ada unsur kominten dan ada unsur kompetensi yang dimiliki perusahaan.

3. Trust demand learning. Kepercayaan merupakan konsep belajar. Untuk menjadi pihak yang dapat dipercaya perlu satu proses pembelajaran. Pembelajaran yang terus-menerus akan menimbulkan kepercayaan.

4. Trust in Tought. Kepercayaan bukan suatu yang mudah. Untuk memperoleh dan mempertahankan suatu kepercayaan membutuhkan suatu proses yang sangat sulit. Untuk itu, pihak produsen harus berhati-hati dalam menjaga kepercayaan yang telah terjaga.

5. Trust need touch. Kepecayaan membutuhkan sentuhan personal. Sentuhan dalam bentuk perhatian atau dalam bentuk jalinan komunikasi yang baik akan menjalin terjadinya kepercayaan.

Selanjutnya terdapat dua dimensi kepercayaan dari para konsumen sebagai pernyataan atas dasar keyakinan dan kesediaan untuk bergantung pada pihak lain yang telah dipercayainya yaitu:

a) Trusting Belief. Trusting Belief merupakan sutau rasa percaya sesorang terhadap sesuatu yang lain. Trusting Belief merupakan persepsi kepercayaan nasabah terhadap pihak bank atas jasa layanan yang diberikan. Mc Knight, et-al dalam Bachman dan Zaheer (2006) menyatakan bahwa ada tiga elemen yang membangun Trusting Belief, yaitu benevolence, integrity dan competence.

b) Trusting Intention.Trusting Intention merupakan situasi dimana sesorang dengan sengaja ingin bergantung pada orang lain dan berlangsung secara pribadi pula. Mc Knight et-al dalam Bachman dan Zaheer (2006) menyatakan bahwa ada dua elemen yang membangun Trusting Intention yaitu willingnes to depend dan subjective probability of depend. 


\section{METODE PENELITIAN}

Hipotesis dalam penelitian ini dirumuskan sebagai berikut:

$\mathrm{H}_{1}$ : Ada pengaruh yang signifikan sosialisasi layanan m-bankingterhadap kepercayaan nasabah Bank NTT Cabang Ende.

$\mathrm{H}_{2}$ : Ada pengaruh yang signifikan persepsi nasabah terhadap kepercayaan nasabah Bank NTT Cabang Ende.

$\mathrm{H}_{3}$ : Ada pengaruh yang signifikan sosialisasi layanan m-bankingdan persepsi nasabah terhadap kepercayaan nasabah Bank NTT Cabang Ende.

Gambaran dari keseluruhan variabel yang terdapat dalam penelitian ini, maka dapat digambarkan kerangka model penelitian sebagai berikut:

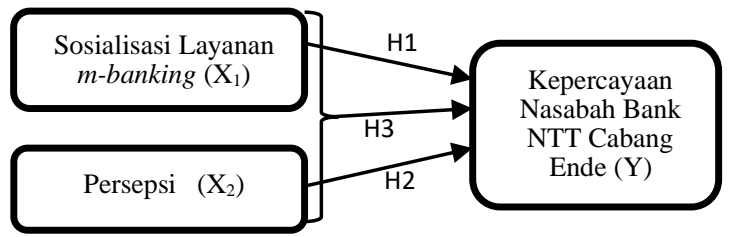

Gambar 1.Model Penelitian

Penelitian ini merupakan penelitian kuantitatif dengan pendekatan deskritif kuantitatif yang bertujuan untuk mengumpulkan, mengelolah, menyajikan, menganalisa dan menginterpretasikan data berupa angka-angka.

Penelitian ini dilakukan di Kantor Cabang Bank NTT dan tempat pelayanan Bank NTT lainnya seperti Kantor Pelayanan Samsat, Kantor Kas Wolowona, Kantor Kas Pemda, Kantor Kas Universitas Flores, dengan populasi penelitian dibatasi pada kelompok ASN Pemerintahan Kabupaten Ende di wilayah Kota Ende per Desember 2018 sebanyak 4.395.

Sampel penelitian dilakukan secara porposive simple random sampling dengan pendekatan accidental sampling. Jumlah sampel ditentukan dengan mengadaptasikan teori Taro Yamane dengan presisi sebesar $10 \%$, diperoleh sampel (n) sebanyak 98 responden (Riduwan, 2009:65). Selanjutnya responden akan mengisi angket, kemudian dianalisis menggunakan teknik analisis regresi linear berganda dengan bantuan program SPSS.

\section{HASIL DAN PEMBAHASAN}

\section{A. Hasil Penelitian}

\section{Uji Validitas}

Uji Validitas instrumen menggunakan bantuan program SPSS v 23.0 dengan ketentuan $r_{\text {hitung }}$ lebih besar dari $r_{\text {tabel }}$ pada level of signifikan 5\%. Hasil uji menunjukkan variabel sosialiasi layanan $m$ banking 10 item valid, variabel persepsi nasabah 7 item valid, sedangkan variabel kepercayaan nasabah 7 item valid.

\section{Uji Reliabilitas}

Uji Reliabilitas dilakukan untuk mengukur suatu kuesioner yang merupakan indikator dari variabel. Reliabel suatu variabel dengan ketentuan nilai Cronbach Alpha (a) >0,70 (Sekaran, 2003:110); Hasil uji reliabilitas menunjukkan variabel sosialiasi layanan m-banking 0,820, variabel persepsi nasabah 0,719, dan variabel kepercayaan nasabah 0,747. Dengan demikian semua item yang terdapat pada instrumen angket memenuhi kriteria reliabel dengan nilai Cronbach alpha adalah $>0,7$.

Memperhatikan hasil uji di atas, dan mempertimbangkan kesamaan jumlah item angket pada tiga variabel maka ditentukan sebanyak tujuh item angket yang selanjutnya akan dijadikan sebagai instrumen angket yang baku.

\section{Uji Normalitas}

Hasil perhitungan normalitas secara statistik yang dilihat berdasarkan uji One-Sample Kolmogorov-Smirnov adalah sebagai berikut: 
Tabel 1.Hasil Uji Normalitas One-Sample Kolmogorov-Smirnov Test

\begin{tabular}{|ll|l|}
\hline \multicolumn{1}{|l|}{ One-Sample Kolmogorov-Smirnov Test } & \multicolumn{1}{l|}{$\begin{array}{l}\text { Unstandardized } \\
\text { Residual }\end{array}$} \\
\hline $\mathrm{N}$ & & 98 \\
$\begin{array}{l}\text { Normal } \\
\text { Parameters }\end{array}$ & Mean &, 0000000 \\
& Std. Deviation & 1,21024863 \\
Most Extreme & Absolute &, 081 \\
Differences & & \\
& Positive &, 056 \\
Test Statistic & Negative &,- 081 \\
Asymp. Sig. (2-tailed) & &, 081 \\
\hline
\end{tabular}

a. Test distribution is Normal.

b. Calculated from data.

c. Lilliefors Significance Correction.

Sumber: Data diolah, 2019

Data pada tabel 1, menunjukan hasil uji normalitas data menggunakan metode Kolmogorov Smirnov, nilai signifikansi masing-masing variabel lebih dari 0,05 , yang berarti data tersebut berdistribusi normal.

\section{Hasil Uji Hipotesis}

Tabel 2. Hasil analisis regresi linear berganda Coefficients $^{\mathrm{a}}$

\begin{tabular}{|c|c|c|c|c|c|}
\hline \multirow{2}{*}{ Model } & \multicolumn{2}{|c|}{$\begin{array}{l}\text { Unstandardized } \\
\text { Coefficients }\end{array}$} & \multirow{2}{*}{$\begin{array}{l}\text { Standardized } \\
\text { Coefficients } \\
\text { Beta }\end{array}$} & \multirow[b]{2}{*}{$\mathrm{t}$} & \multirow{2}{*}{ Sig. } \\
\hline & B & $\begin{array}{l}\text { Std. } \\
\text { Error }\end{array}$ & & & \\
\hline 1 (Constant) & 5,863 &, 939 & & 6,243 & ,000 \\
\hline Sosialisasi & ,258 & ,087 & ,297 & 2,949 & ,004 \\
\hline Persepsi & ,063 &, 110 & ,057 & ,569 & ,571 \\
\hline
\end{tabular}

a. Dependent Variable: Kepercayaan

\begin{tabular}{|c|c|c|c|}
\hline Alfa & \multicolumn{3}{|c|}{$: 5 \%$} \\
\hline $\mathrm{R}$ & \multicolumn{3}{|c|}{$: 0,128$} \\
\hline R square & \multicolumn{3}{|c|}{0,16} \\
\hline Adjusted $\mathrm{R}$ square & \multicolumn{3}{|c|}{$: 0,004$} \\
\hline F hitung & : & F Tabel & $\begin{array}{l}: \mathbf{2 , 8 1} \\
: 175305\end{array}$ \\
\hline $\begin{array}{l}\text { Sig F } \\
\mathbf{0 , 4 5 6}\end{array}$ & : & & \\
\hline
\end{tabular}

Sumber: Data primer diolah, 2019

Berdasarkan tabel di atas dapat diperoleh model persamaan regresi sebagai berikut:

$$
Y=5,863+0,258 X_{1}+0,258 X_{2}
$$

Konstanta (a) sebesar 5,863; artinya apabila sosialaisasi layanan m-banking dan persepsi tidak ada atau nilainya 0 , maka kepercayaan nasabah akan layanan m-banking nilainya sebesar 5,863. Koefisien regresi variabel sosialisasi $\left(\mathrm{X}_{1}\right)$ sebesar 0,258 ; artinya apabila sosialisasi ditingkatkan 1 satuan, maka kepercayaan nasabah mengalami kenaikan sebesar 25,8\%. Koefisien bernilai positif artinya ada hubungan positif antara sosialisasi dengan kepercayaan nasabah. Semakin tinggi tingkat sosialisasi, maka semakin tinggi pula kepercayaan nasabah akan layanan m-banking. Koefisien regresi variabel persepsi $\left(\mathrm{X}_{2}\right)$ sebesar 0,063. Artinya apabila persepsi ditingkatkan 1 satuan, maka kepercayaan nasabah mengalami kenaikan sebesar 6,3\%. Koefisien bernilai positif artinya terjadi hubungan searah persepsi dengan kepercayaan nasabah. Semakin tinggi persepsi nasabah maka akan semakin meningkatkan kepercayaan nasabah akan layanan $m$-banking.

\section{Hasil Uji Parsial (Uji t)}

Tabel 3. Hasil Uji t Coefficients $^{\mathrm{a}}$

\begin{tabular}{|c|c|c|c|c|c|c|}
\hline \multirow{2}{*}{ Model } & \multicolumn{3}{|c|}{\begin{tabular}{|l} 
Unstandardized \\
Coefficients \\
\end{tabular}} & \multirow{2}{*}{$\begin{array}{l}\text { Standardized } \\
\text { Coefficients } \\
\text { Beta }\end{array}$} & \multirow[b]{2}{*}{$\mathrm{t}$} & \multirow[b]{2}{*}{ Sig. } \\
\hline & B & & $\begin{array}{l}\text { Std. } \\
\text { Error }\end{array}$ & & & \\
\hline \multirow[t]{3}{*}{1} & (Constant) & 4,793 &, 724 & & 6,619 &, 000 \\
\hline & Sosialisasi &, 020 & ,102 & ,021 & ,194 &, 847 \\
\hline & Persepsi & , 143 & ,128 &, 120 & 1,118 & ,266 \\
\hline
\end{tabular}

Berdasarkan tabel di atas diketahui nilai $\mathrm{t}$ hitung dari variabel pengaruh sosialisasi layanan m-banking terhadap kepercayaan nasabah menunjukan nilai $t_{\text {hitung }} 0.194$ lebih kecil dari nilai $t_{\text {tabel }} 1.985$ dengan nilai sig. sebesar 0,847 lebih besar dari 0,05. Dengan demikian hipotesis yang diajukan tidak diterima. Artinya variabel sosialisasi layanan $m$-banking tidak berpengaruh terhadap kepercayaan nasabah Bank NTT Cabang Ende.

Selanjutnya variabel pengaruh persepsi nasabah terhadap kepercayaan nasabah menunjukan nilai thitung 1,118 lebih kecil dari nilai $t_{\text {tabel }} 1,985$ dengan nilai sig. 0,266 lebih besar dari 0,05. Dengan demikian hipotesis yang diajukan tidak diterima. Artinya variabel persepsi nasabah tidak berpengaruh terhadap kepercayaan nasabah Bank NTT Cabang Ende. 


\section{Hasil Uji simultan (Uji F)}

Tabel 4. Hasil uji F

\begin{tabular}{|c|c|c|c|c|c|}
\hline Model & $\begin{array}{l}\text { Sum of } \\
\text { Squares }\end{array}$ & df & $\begin{array}{l}\text { Mean } \\
\text { Square }\end{array}$ & $\mathrm{F}$ & Sig. \\
\hline $\begin{array}{ll}1 & \text { Regression } \\
& \text { Residual } \\
& \text { Total } \\
\end{array}$ & $\begin{array}{l}2,274 \\
136,501 \\
138,776 \\
\end{array}$ & \begin{tabular}{|l|}
2 \\
95 \\
97 \\
\end{tabular} & $\begin{array}{l}1,137 \\
1,437\end{array}$ & ,791 &, $456^{\mathrm{b}}$ \\
\hline
\end{tabular}

a. Dependent Variable: Kepercayaan

b. Predictors: (Constant), Persepsi, Sosialisasi

Sumber: Data diolah, 2019

Hasil uji $\mathrm{F}$ menunjukkan bahwa variabel pengaruh sosialisasi layanan m-banking, dan variabel persepsi secara bersama-sama menunjukkan nilai $F_{\text {hitung }} 0,791$ lebih kecil dari nilai $\mathrm{F}_{\text {tabel } 3,90}$ dengan nilai sig. 0,456 lebih besar dari 0,05 . Dengan demikian hipotesis yang diajukan tidak diterima. Artinya variabel sosialisasi layanan m-banking dan persepsi nasabah secara simultan tidak berpengaruh terhadap kepercayaan nasabah Bank NTT Cabang Ende.

\section{Koefisien Determinasi}

Hasil perhitungan koefisien determinasi (R) menunjukkan bahwa besarnya kontribusi pengaruh variabel bebas (sosialisasi layanan m-banking, persepsi nasabah) dalam mempengaruhi variabel terikat (kepercayaan nasabah Bank NTT Cabang Ende) ditunjkkan dengan nilai $\mathrm{R}$ 0,128. Artinya pengaruh variabel bebas terhadap variabel terikat sebesar $12,8 \%$ atau $87,2 \%$ dipengrauhi oleh variabel diluar dari variabel yang diteliti, dengan kesalahan pengukuran sebagaimana yang terlihat pada nilai $\mathrm{R}$ square 0,016 atau $0,16 \%$ dan keakuratan prediksi pengaruh variabel bebas terhadap variabel terikat seperti terlihat pada Adjusted R Square sebesar -0,004. Keakuratan model regresi sebesar 1,19869. Dengan demikian akurasi model yang terbentuk sebesar $98.03131 \%$.

Tabel 5. Hasil Uji Koefisien Determinasi

Model Summary
\begin{tabular}{|l|l|l|l|l|}
\hline & & & Adjusted & $\begin{array}{l}\text { Std. Error } \\
\text { of the } \\
\text { Model }\end{array}$ \\
\hline 1 & R & R Square & R Square & Estimate \\
\hline
\end{tabular}

a. Predictors: (Constant), Persepsi, Sosialisasi

Tabel model summary di atas menunjukan besarnya pengaruh dari seluruh variabel bebas terhadap variabel terikat yang ditunjukan dengan $\mathrm{R}$ (korelasi) 0,128 artinya pengaruh variabel sosialisasi layanan m-banking, dan variabel persepsi terhadap kepercayaan nasabah Bank NTT Cabang Ende sebesar $12,8 \%$. Dengan demikian 87,2\% terkontaminasi oleh variabel-variabel lainnya diluar model yang dimasukkan dalam penelitian ini. Nilai banyaknya kesalahan dalam memprediksi kepercayaan nasabah Bank NTT Cabang Ende sebesar 1,19869. Hal ini memperlihatkan tingkat akurasi model regresi pada standard error of the estimate, sebesar $98.80131 \%$.

Uji parsial dan uji simultan secara ringkas digambarkan dalam model penelitian sebagai berikut:

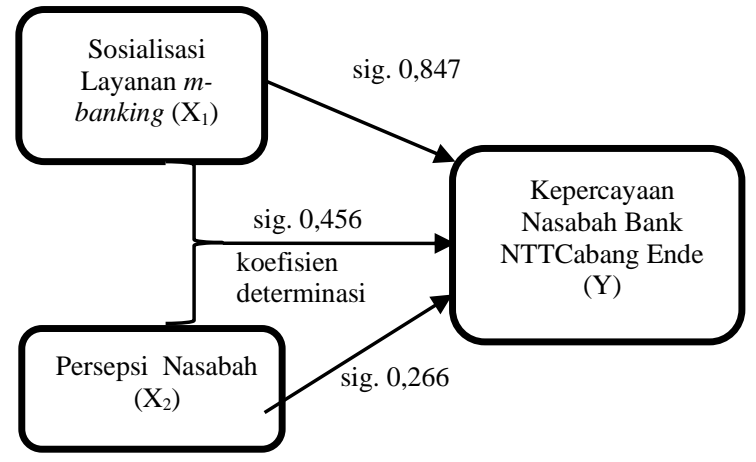

Gambar 2. Bagan hasil analisis dalam model penelitian

\section{B. Pembahasan}

Hasil pengujian hipotesis pada penelitian ini adalah sebagai berikut:

1. Pengaruh sosialisasi layanan m-banking terhadap kepercayaan nasabah Bank NTT Cabang Ende.

Hasil uji parsial menunjukkan bahwa hipotesis yang diajukan dinyatakan ditolak, artinya sosialisasi layanan $m$-banking tidak memiliki pengaruh yang signifikan terhadap kepercayaan nasabah Bank NTT Cabang Ende dibuktikan dengan uji $\mathrm{t}$ 
sig>0.05. Makna yang terdapat pada signifikansi ini dapat dijelaskan, jika managemen Bank NTT Cabang Ende tidak melakukan sosialisasi layanan m-banking maka tidak mempengaruhi kepercayaan nasabah. Atau dengan kata lain jika managemen tidak melakukan sosialisasi layanan $m$-banking, nasabah sesungguhnya telah mempercayai Bank NTT Cabang Ende sebesar 12,8\%.

Hasil penelitian ini menunjukkan perbedaan dengan hasil penelitian yang dilakukan Heri Setiawan bahwa variabel kualitas layanan berpengaruh signifikan terhadap kepuasan konsumen. Signifikansinya ditunjukkan oleh nilai CR sebesar 3.108 dan probabilitas signifikansinya 0.002 lebih kecil dari taraf signifikansi $(\alpha)$ yang ditentukan yaitu $<\quad 0.05$. Hipotesis penelitian yang menyatakan bahwa kualitas layanan berpengaruh signifikan terhadap kepuasan konsumen terbukti (diterima) sebesar $28 \%$. Penelitian ini mendukung penelitian Khan dan Fasih (2014) yang menyatakan bahwa kualitas pelayanan dan semua dimensi memiliki signifikan dan positif hubungan dengan kepuasan pelanggan.

2. Pengaruh persepsi nasabah terhadap kepercayaan nasabah Bank NTT Cabang Ende.

Hasil uji parsial menunjukkan bahwa hipotesis yang diajukan dinyatakan ditolak, artinya persepsi nasabah tidak memiliki pengaruh yang signifikan terhadap kepercayaan nasabah Bank NTT cabang Ende dibuktikan dengan uji $\mathrm{t}$ sig $>0.05$. Dengan demikian kepercayaan nasabah terhadap Bank NTT sesungghunya sudah dimiliki sebesar $12,8 \%$ walaupun tidak komprehensif. Hal ini dapat terjadi karena faktor kemitraan antar institusi, image nasabah terhadap keberadaan Bank NTT yang melayani kebutuhan para nasabah. Hasil penelitian ini sama dengan hasil uji parsial dalam risetnya Hardi dan Dwi (2007) serta Sartika dan Zaki (2013).

3. Secara simultan pengaruh variabel sosialisasi layanan $m$-banking dan persepsi nasabah terhadap kepercayaan nasabah
Bank NTT Cabang Ende tidak memiliki pengaruh yang signifikan ( uji $\mathrm{F}$ sig. > $0,05)$. Dengan demikian dua hal tersebut tidak perlu dilakukan pada nasabah segmen ASN Pemerintah Kabupaten Ende. Sosialisasi layanan m-banking dalam rangka membangun persepsi nasabah dapat dilakukan pada segmen nasabah lainnya untuk mewujudkan Bank NTT yang terpercaya.

\section{SIMPULAN DAN SARAN}

Hasil analisis dan pembahasan menunjukkan uji parsial untuk variabel $X_{1}$ terhadap $\mathrm{Y}$, uji parsial untuk variabel $\mathrm{X}_{2}$ terhadap $\mathrm{Y}$, dan uji simultan variabel $\mathrm{X}_{1}$ dan $\mathrm{X}_{2}$ terhadap $\mathrm{Y}$, terbukti tidak memiliki pengaruh signifikan yang ditunjukkan dengan uji t sig >0,05 dan uji f sig. >0,05. Dengan demikian disimpulkan bahwa hipotesis yang diajukan "Ada pengaruh yang signifikan sosialisasi layanan m-banking dan persepsi nasabah terhadap kepercayaan nasabah Bank NTT Cabang Ende, dinyatakan "ditolak".

Kesimpulan di atas menyiratkan saran untuk melakukan sosialisasi layanan $m$-banking bagi nasabah kategori non ASN, sembari tetap memaksimalkan layanan dan menjaga kemitraan dengan ASN Pemkab Ende untuk mewujudkan visi, misi Bank NTT dalam semangat "melayani lebih sungguh".

\section{DAFTAR PUSTAKA}

A. S. Moenir. 2010. Manajemen pelayanan umum di Indonesia. Jakarta. Bumi Aksara.

Asmara, Damar Aryateja. 2006. Peranan Notariat Sebagai Pejabat Lelang dalam Upaya Sosialisasi Lelang di Indonesia. Semarang: Naskah Publikasi Universitas Diponegoro.https://ejournal.ilkom.fisipunmul.ac.id/site/wpcontent/uploads/2015/0 1/jurnal\%20ariny\%20(01-29-15-07-4019).pdfdiunduh15/03/2019.

Bachman, R., Akbar, Z. 2006. Handbook of Trust Research. USA: Edwar Elgar Publising Inc.

Cronin, J. \& A, Taylor. 1992. Measuring Service Quality: A Reexamination and 
Extension, Journal of Marketing,56 (3): 5558.

Effendy, Onong Uchjana. 2003. Ilmu, Teori \& Filsafat Komunikasi. Bandung: Citra Aditya Bakti.

Harish Nurahmadi Irfan (2017). Pengaruh Kepercayaan Nasabah dan Kualitas Layanan Mobile Banking Terhadap Kepuasan Nasabah. Jakarta. Universitas Islam Negeri Syarif Hidayatullah.

Heri Setiawan. 2014. Pengaruh Kualitas Layanan, Persepsi Nilai Dan Kepercayaan Terhadap Kepuasan Dan Loyalitas Pengguna Layanan Mobile Banking. Jurnal Keuangan Dan Perbankan, Vol.20, No.3 September 2016, Hlm. 518-528 Terakreditasi Sk. No. 040/P/2014 Http://Jurnal.Unmer.Ac.Id/Index.Php/Jkdp. diunduh 17/3/2019.

Hadri Kusuma dan Dwi Susilowati. 2007. Determinan Pengadopsian Layanan Internet Banking Perspektif Konsumen Perbankan Daerah Istimewa Yogyakarta. Jurnal Akuntansi dan Auditing Indonesia (Online), Volume 11, No. 2: 105-124, (http://journal.uii.ac.id).diunduh 17/3/2019.

Novitasari Putri Wulandari, Nadya Novandriani Karina Moeliono. 2017. Analisis Faktor-Faktor Penggunaan Layanan Mobile Banking Di Bandung.Bisnis dan Iptek Vol.10, No. 2, Oktober 2017, 139-149 ISSN : 2502-1559.

Oetomo, Budi Sutedjo Dharma. 2006. Perencanaan dan pengembangan sistem informasi. Yogyakarta.Andi.

Philip

Kotller.2006. 2003:464.https://www.seputarpengetahuan. co.id/ diunduh 2/3/2019.

Rakhmat Jalaluddin. 2012. Psikologi komunikasi. Bandung. PT Remaja Rosdakarya.

Robbins P. Stephen \& Coulter Mary. 2003. Manajemen. PT. Gelora Aksara Pratama; Erlanga.

Riduwan. 2009. Metode dan Teknik Menyusun Tesis. Bandung. Alfabeta.
Syamsul Rizal, Munawir. 2017. Pengaruh Kepuasan Nasabah Terhadap Menggunakan Mobile Banking (M-Banking) Pada Bank BCA Cabang Banda Aceh.Jurnal Ekonomi dan Manajemen Teknologi, 1(2), 2017,6878.

Selly Maulina, Dahlan, Mujibussalim. 2016. Kanun Jurnal Ilmu Hukum Vol. 18, No. 3, (Desember, 2016), pp. 353-365.

Sartika Sari Ayu Tjini dan Zaki Baridwan. 2013. Pengaruh Kepercayaan, Persepsi Kegunaan, Persepsi Kemudahan, dan Persepsi Kenyamanan Terhadap Minat Penggunaan Sistem Internet Banking. Jurnal Imliah Mahasiswa FEB (Online), Vol. 1, No. 2.

Tony Wijaya. 2003. Analisis Data Penelitian menggunakan SPSS. Yogyakarta. Universiatas Atama Jaya Yogyakarta.

Yuwono Dwi Zepri. 2015. Pengaruh Sosialalisasi Terhadap Kesadaran dan Kepatuhan Wajib Pajak Bumi dan Bangunan di Kota Kediri. Universitas Nusantara.

Zeithaml, V. A. Berry, L. L. \& Parasuraman, A. 1996.The Behavioral Consequences of Service Quality, Journal ofMarketing, 60 (2): 31-46. 